\title{
PERAN PENDIDIKAN KARAKTER DALAM \\ MENGANTISIPASITINDAKKRIMINALITAS SISWA DI SEKOLAH MENENGAH KEJURUAN NEGERI (SMKN)1 SINDANG INDRAMAYU
}

\author{
Ahmad Zahir Abdali ${ }^{1}$, Aris Suherman ${ }^{2}$ \\ IAIN Syekh Nurjati Cirebon ${ }^{1,2}$ \\ abdalizahir17@gmail.com;indrinurindie@yahoo.com
}

\begin{abstract}
Abstrak
Masalah kenakalan remaja, khususnya remaja usia sekolah atau remaja yang masih duduk dibangku sekolah mulai memasuki tingkat menghawatirkan karena sudah masuk ranah kriminalitas. Masalah ini bukan hanya tanggung jawab orang tua dan masyarakat saja tetapi juga tanggung jawab guru dan sekolah untuk mengatasi masalah tersebut, karena sekolah sebagai lembaga pendidikan formal yang diangap paling bertanggung jawab terhadap hasil pendidikan karakter seorang siswa. Oleh karena itu perlu adanya perhatian dan upaya sekolah untuk menanggulangi masalah tindak kriminalitas siswa secara dini. Penelitian ini bertujuan untuk memperoleh data tentang bagaimana peran pendidikan karakter dalam mengatasi tindak kriminalitas, serta peran pendidikan karakter dalam membentuk perilaku social siswa yang disiplin dan baik di SMKN I Sindang Indramayu.Dalam proses pendidikan harus bisa memahami fungsi sebuah tanggung jawab yang mesti dijalani dan tidak bisa ditinggalkan untuk orientasi memberikan bimbingan yang maksimal kepada peserta didik serta sesuai dengan makna pendidikan itu sendiri mencerdaskan anak bangsa juga memiliki sebuah etika dan akhlak yang baik.Penelitian ini menggunakan pendekatan kualitatif dengan jenis penelitian metode kualitatif deskriptif, sedangkan dalam pengumpulan data dilaksanakan dengan teknik observasi, wawancara dan dokumentasi untuk mendapatkan informasi mengenai masalah yang diteliti. Sedangkan menganalisis data yang digunakan adalah data reduction (reduksi data), data display (penyajian data) dan conclusion drawing / verification (penarikan kesimpulan).Berdasarkan analisis untuk penelitian ini dapat disimpulkan bahwa, peran pendidikan karakter dalam mengantisipasi tindak kriminalitas siswa sangat relevan, disebabkan melalui kegiatan proses pendampingan dalam pembelajaran secara etika dan akhlak yang disempurnakan lebih baik. Menanamkan nilai-nilai perilaku sosial dilakukan melalui beberapa unsur pendidikan yang meliputi adanya tahap perencanaan, pelaksanaan, keteladanan, dan kegiatan ekstrakurikuler di SMK Negeri 1 Sindang Indramayu dengan melalui kegiatan yang rutin, kegiatan yang spontan, dan kegiatan yang terprogram. Hal tersebut bisa dilihat dari sebuah aktifitas keseharian di lingkungan sekolah bertahap memiliki etika dan akhlak yang baik.
\end{abstract}

Kata Kunci : Peran Pendidikan Karakter, Sikap Sosial 


\begin{abstract}
Problems of juvenile delinquency, especially school-age teenagers or adolescents who are still sitting in the school began to enter the level of worry because it has entered the realm of criminality. This issue is not only the responsibility of the parents and the community but also the responsibility of teachers and schools to overcome the problem because the school as a formal educational institution is considered the most responsible for the educational outcome of a student's character. Therefore, the need for attention and effort of school to overcome the problem of student crime early on.This study aims to obtain data about how the role of character education in overcoming crime, as well as the role of character education in shaping social behavior of disciplined students and good at SMKN I Sindang Indramayu.In the process of education should be able to understand the function of a responsibility that must be lived and can not be left to orientation to provide maximum guidance to learners and in accordance with the meaning of education itself educating children of the nation also has a good ethics and morals.This research uses the qualitative approach with descriptive qualitative research method, while in collecting data is done by observation, interview and documentation to get information about the problem under study. While analyzing the data used are data reduction (data reduction), display data (presentation data) and conclusion drawing/verification (drawing conclusions).Based on the analysis for this study can be concluded that the role of character education in anticipating the crime of students is very relevant, caused through the process of mentoring activities in learning ethics and morals are perfected better. Embedding the values of social behavior is done through several elements of education which include the stage of planning, execution, exemplary, and extracurricular activities in SMK Negeri 1 Sindang Indramayu through routine activities, spontaneous activities, and programmed activities. It can be seen from a daily activity in the school environment gradually have good ethics and morals.
\end{abstract}

\title{
Keywords :Character Education Roles, Social Attitudes
}

\section{A. PENDAHULUAN}

\section{Latar Belakang Masalah}

Pendidikan karakter adalah usaha sadar dan terencana dalam menanamkan nila-nilai sehingga terinternalisasi dalam diri peserta didik yang mendorong dan mewujud dalam perilaku dan sikap yang baik, sedangkan menurut Lickona $\mathrm{T}$ adalah suatu usaha yang disengaja untuk membantu seseorang sehingga ia dapat memahami, memperhatikan, dan melakukan nilai-nilai etika yang inti (Lickona. 2009: 14).

Pendidikan yang sangat dibutuhkan saat ini adalah pendidikan yang dapat mengintegrasikan pendidikan karakter dengan pendidikan yang 
dapatmengoptimalkan perkembangan seluruh dimensi anak (kognitif, fisik, sosial-emosi, kreativitas, dan spiritual).Pendidikan dengan model pendidikan seperti ini berorientasi pada pembentukan anak sebagai manusia yang utuh.Kualitas anak didik menjadi unggul tidak hanya dalam aspek kognitif, namun juga dalam karakternya. Anak yang unggul dalam karakter akan mampu menghadapi segala persoalan dan tantangan dalam hidupnya. Ia juga akan menjadi seseorang yang life long learner (Soekidjo Notodatmodjo. 2003 : 16).

Jika diamati amanat Undang-undang Nomor 20 Tahun 2003 tentang Sistem Pendidikan Nasional, lembaga pendidikan (sekolah) memang merupakan wahana bagi pendidikan karakter. Tidak tersentuhnya nurani atau moral siswa ini memunculkan berbagai keluhan terhadap sekolah. Menurut Subagio (2007:15), ada beberapa alasan yang menyebabkan anak (siswa) mengeluh mengenai sekolahnya. Banyak keluhan mengenai sekolah itu mencerminkan perjuangan yang normal pada masa anak-anak. Oleh karena itu, masalah kenakalan remaja khususnya di kalangan siswa/pelajar perlu mendapat perhatian dan penanganan secara professional serta berkelanjutan antara lain oleh guru, sekolah dan orang tua siswa. Hal ini mengingat semakin majunya dunia terlebih pada era globalisasi dewasa ini, semakin banyak godaan dan tuntutan kehidupan yang cenderung mendorong sikap mental serta perilaku menyimpang setiap individu.Untuk menanggulangi dan mencegah munculnya perilaku menyimpang atau kenakalan di kalangan siswa, maka perlu upaya pembinaan terhadap siswa secara terintegrasi antara sekolah dengan orang tua siswa, dan masyarakat.Pembinaan ini dapat efektif dan efisien.

\section{Rumusan Masalah}

Berdasarkan latar belakang di atas maka rumusan masalah dalam penelitian ini adalah:

a. Bagaimana pendidikan karakter di SMKN 1 Sindang Indramayu?

b. Bagaimana karakter siswa di SMKN 1 Sindang Indramayu .?

c. Bagaimana peran pendidikan karakter dalam membentuk perilaku social siswa diSMKN 1 SindangIndramayu? 


\section{Tujuan Penelitian}

Sesuai dengan perumusan masalah, maka tujuan penelitian yang akan dilaksanakan yaitu

a. Mendeskripsikan bagaimana pendidikan karakter di SMKN 1 Sindang Indramayu.

b. Mendeskripsikan karakter siswa di SMKN I Sindang Indramayu.

c. Mendeskripsikan peran pendidikan karakter dalam membentuk prilaku sosial siswa di SMKN I Sindang Indramayu.

\section{B. KAJIAN TEORI}

\section{Pengertian Pendidikan Karakter}

Pendidikan karakter adalah suatu sistem penanaman nilai-nilai karakter kepada warga sekolah yang meliputi komponen pengetahuan, kesadaran atau kemauan, dan tindakan untuk melaksanakan nilai-nilai tersebut, baik terhadap Tuhan Yang Maha Esa (YME), diri sendiri, sesama, lingkungan, maupun kebangsaan sehingga menjadi manusia insan kamil. Dalam pendidikan karakter di sekolah, semua komponen (stakeholders) harus dilibatkan, termasuk komponen-komponen pendidikan itu sendiri, yaitu isi kurikulum, proses pembelajaran dan penilaian, kualitas hubungan, penanganan atau pengelolaan mata pelajaran, pengelolaan sekolah, pelaksanaan aktivitas atau kegiatan ko-kurikuler, pemberdayaansarana, prasarana dan pembiayaan, ethos kerja seluruh warga dan lingkungan sekolah(Kertajaya H .2010: 14).

\section{Fungsi Pendidikan Karakter}

Pendidikan karakter pada intinya bertujuan membentuk bangsa yang tangguh, kompetitif, berakhlak mulia, bermoral, bertoleran, bergotong royong, berjiwa patriotik, berkembang dinamis, berorientasi ilmu pengetahuan dan teknologi yang semuanya dijiwai oleh iman dan takwa kepada Tuhan yang Maha Esa berdasarkan Pancasila. Pendidikan karakter berfungsi untuk:

a. Mengembangkan potensi dasar agar berhati baik, berpikiran baik, dan berperilaku baik 
b. Memperkuat dan membangun perilaku bangsa yang multikultur

c. Meningkatkan peradaban bangsa yang kompetitif dalam pergaulan dunia.

Pendidikan karakter dilakukan melalui berbagai media yang mencakup keluarga, satuan pendidikan, masyarakat sipil, masyarakat politik, pemerintah, dunia usaha, dan media massa.

\section{Manajemen Pendidikan Karakter}

Pendidikan karakter yang dimasudkan disini lebih berkaitan dengan bagaimana menanamkan nilai-nilai tertentu dalam diri anak didik, seperti nilai-nilai yang berguna bagi pengembangan pribadinya sebagai mahluk individual sekaligus sosial dalam lingkungan sekolah.Menurut Murphy (1998) pendidikan karakter secara sederhana bisa didefinisikan sebagai, "pemahaman, perawatan, dan pelaksanaan keutamaan (practice virtue). Oleh karena itu, pendidikan karakter di sekolah mengacu pada proses penanaman nilai, berupa pemahaman-pemahaman, tatacara merawat dan menghidupi nilai-nilai itu, serta bagaimana seorang siswa memiliki kesempatan untuk dapat melatihkan nilai-nilai tersebut secara nyata.

\section{Faktor-Faktor yang Mempengaruhi Pendidikan Karakter}

V. Campbell dan R. Obligasi (1982:35) menyatakan ada beberapa faktor yang berpengaruh dalam pembentukan karakter seseorang:

a. Faktor keturunan

b. Pengalaman masa kanak-kanak

c. Pemodelan oleh orang dewasa atau orang yang lebih tua

d. Pengaruh lingkungan sebaya

e. Lingkungan fisik dan social

f. Subtansi materi di sekolah atau lembaga pendidikan lain

g. Media massa

\section{Model Penerapan Pendidikan Karakter}

Untuk mengimplementasikan pendidikan karakter di sekolah terdapat empat tawaran model penerapan, yaitu

a. Model otonomi dengan menempatkan pendidikan karakter sebagai mata pelajaran tersendiri. 
b. Model integrasi dengan menyatukan nilai-nilai dan karakter-karakter yang akan dibentuk dalam setiap mata pelajaran

c. Model ekstrakurikuler melalui sebuah kegiatan tambahan yang berorintasi pembinaan karakter siswa, dan

d. Model kolaborasi dengan menggabungkan ketiga model tersebut dalam seluruh kegiatan sekolah.

\section{Kajian Penelitian yang Relevean}

Nina Unun Yulista mahasiswa Prodi Pendidikan Pancasila dan Kewarganegaraan, Jurusan Hukum dan Kewarganegaraan, Fakultas Ilmu Sosial Universitas Negeri Malang (2011). Dengan judul: Upaya Sekolah dalam Menanggulangi Kenakalan Siswa di SMP Negeri I Panji Kabupaten Situbondo. Penelitian ini menggunakan pendekatan kualitatif dengan rancangan studi kasus di SMP Negeri I Panji Kabupaten Situbondo.Subyek penelitian ini adalah kepala sekolah, Guru PKN, Guru BP/BK dan siswa.

1) Persamaan

a) Sama-sama meneliti tentang peran pendidikan karakter dalam membentuk karakter siswa.

b) Sama-sama meneliti tentang perilaku siswa.

2) Perbedaan

Perbedaanya terletak pada waktu dan tempat serta jenis penelitian.

\section{METODOLOGI}

\section{Jenis Penelitian}

Jenis penelitian dalam skripsi iniadalah kualitatif. Yaitu suatu pendekatan yang juga disebut pendekatan investigasi karena biasanya peneliti mengumpulkan data dengan cara bertatap muka langsung dan berinteraksi dengan orang orang di tempat penelitian (McMilan \& Schumacher, 2003:18) Penelitian kualitatif (qualitative research) bertolak dari filsafat konstruktivisme yang berasumsi bahwa kenyataan itu berdimensi jamak, interaktif dan suatu pertukaran pengalaman social (a 
share social eperience) yang diiterpretasikan oleh individu-individu (Nana Syaodih, $2001: 94$ ).

\section{Tempat dan Waktu Penelitian}

Penelitian ini dilaksanakana di SMKN 1 Sindang Kab.Indramayu, dengan waktu pelaksanaan selama 3 (tiga) bulan yaitu mulai tanggal 09 Agustus s/d 09 Oktober 2016 Yang dilakukan secara bertahap dengan tahapan sebagai berikut :

a. Tahap persiapan, mencakup pengajuan judul, pembuatan proposal, pencarian referensi yang relevan dengan penelitian, pembuatan instrument/ angket. Permohonan ijin penelitian SMKN1 Sindang Indramayu sebagai tempat penelitian. Jangka waktu pelaksanaan penelitian.

b. Tahap pelaksanaan, yaitu kegiatan kegiatan penelitian yang berlangsung di SMKN 1 Sindang Kab. Indramayu yang meliputi Observasi, Wawancara dan Angket waktu yang dibutuhkan dalam tahap pelaksanaan kurang lebih 3 bulan.

c. Tahap penyusunan laporan, yaitu tahap pengolahan data, konsultasi dengan dosen pembimbing 1 dan 2 yang di ikuti dengan penyusunan skripsi mulai penyusunan skripsi mulai penyusunan BAB 1 sampai dengan selesai, serta melakukan persiapan uji munaqosah.

\section{Subjek Penelitian}

Pada penelitian ini yang menjadi subjek adalah kepala sekolah 1 orang,wakil kurikulum, 2 orang guru BK,dan wali kelas 3 orang. Dengan demikan, jumlah total dari keseluruhan responden ialah berjumlah 7 orang. Aktifitas yang tengah atau pernah dilakukan oleh aktor atau informan meliputi aktivitas yang berhubungan dengan upaya kepala sekolah dalam meningkatkan partisipasi orang tua untuk mendukung program sekolah mulai dengan komunikasi dengan masyarakat dan seluruh komponen sekolah.

\section{Tekhnik Pengumpulan Data}

Dalam penelitian ini penulis menggunakan triangulasi teknik yang berarti peneliti menggunakan teknik pengumpulan data yang berbeda-beda 
untuk mendapatkan data dari sumber yang sama. Peneliti menggunakan observasi paratisipatif, wawancara mendalam dan dokumentasi untuk sumber data yang sama secara serempak (Sugiyono, 2013: 330).

\section{Instrumen Pengumpulan Data (IDP)}

Pengumpulan data dalam penelitian kualitatif dapat dilakukan dengan menggunakan teknik kondisi yang alami, sumber data primer, dan lebih banyak pada teknik observasi berperan serta, wawancara mendalam, studi dokumentasi dan triangulasi (Sugiyono, 2013: 309).

a. Observasi Partisipatif (participanobservation).

Observasi atau pengamatan adalah kegiatan keseharian manusia dengan menggunakan pancaindra mata sebagai alat bantu utamanya selain pancaindra lainya seperti telinga, penciuman, mulut dan kulit. Observasi adalah kemampuan seseorang untuk menggunakan pengamatanya melalui hasil kerja pancaindra mata serta dibantu dengan pancaindra lainya. Sesungguhnya metode observasi adalah metode pengumpulan data yang digunakan untuk menghimpun data penelitian melalui pengamatan dan pengindraan (Burhan, 2007: 115).

b. Wawancara Mendalam (depth interview)

Metode wawancara secara umum adalah proses memperoleh keterangan untuk tujuan penelitian dengan cara tanya jawab sambil bertatap muka antara pewawancara dengan informan atau orang yang diwawancarai, dengan atau tanpa menggunakan pedoman wawancara, di mana pewawancara dan informan terlibat dalam kehidupan sosial yang relatif lama. Dengan demikian, kekhasan wawancara mendalam adalah keterlibatanya dalam kehidupan informan.

c. Studi Dokumentasi

Dokumen merupakan catatan peristiwa yang sudah berlalu. Dokumen bisa berbentuk lisan, gambar atau karya-karya monumental dari seseorang. Dokumen yang berbentuk lisan misalnya catatan harian, sejarah kehidupan (life history), cerita, biografi, peraturan dan kebijakan. Dokumen yang berbentuk gambar misalnya foto, gambar hidup, sketsa dan lain-lain. Dokumen yan berbentuk karya misalkan karya seni yang dapat 
berupa gambar, patung, film dan lain-lain. Studi dokumen merupakan pelengkap dari penggunaan metode wawancara dan observasi dalam penelitian kualitatif (Sugiyono, 2013: 329).

\section{Tekhnik Analisis Data}

a. Data Reduction (Reduksi Data)

Mereduksi data berarti merangkum, memilih hal-hal yang pokok, memfokuskan pada hal-hal yang penting, dicari tema dan polanya. Data yang telah direduksi akan memberi gambaran yang lebih jelas, dan mempermudah peneliti untuk melakukan pengumpulan data selanjutnya, dan mencarinya bila diperlukan

b. Data Display (Penyajian Data)

Setelah data direduksi, langkah selanjutnya adalah mendisplaykan data. Dalam penelitian kualitatif, penyajian data bisa dilakukan dalam bentuk uraian singkat, bagan hubungan antar kategori, flowchart dan sejenisnya

c. Conclusion Drawing/Verification(Penarikan Kesimpulan)

Langkah ketiga dalam analisis data kualitatif perspektif Miles and Huberman adalah penarikan kesimpulan dan verifikasi

\section{HASIL PENELITIAN DAN PEMBAHASAN}

\section{Kegiatan Pendidikan di SMKN 1 Sindang Indramayu}

Guna memperoleh data tentang menanamkan nilai-nilai perilaku sosial di SMK Negri 1 Sendnag Indramayu dilakukan dengan wawancara dengan beberapa responden. Adapun responden dalam penelitian ini yaitu wakil kepala sekolah bidang kurikulum, guru dan siswa-siswi kelas VIIVIII-IX.

Menanamkan nilai-nilai perilaku sosial siswa di SMK Negri 1 Sindang Indramayu semua pihak atau komponen sekolah yang ada di SMK Negri 1 Sindang Indramayu. Pembinaan karakterpun harus dilakukan oleh semua pihak komponen sekolah, bukan hanya tanggung jawab lembaga sekolah dan guru mata pelajaran saja. Dengan demikian, kurang tepat jika dikatakan bahwa pendidik dan pembimbing para peserta 
didik agar memiliki karakter hanya dilimpahkan pada lembaga sekolah dan guru. Melainkan oleh semua komponen sekolah, agar guru, staf dan karyawan serta masyarakat di sekitar lingkungan sekolah itu sendiri harus turut serta dalam menanamkan nilai-nilai perilaku sosial pada peserta didik di SMK Negri 1 Sindang Indramayu.

Proses pendidikan di SMK Negri 1 Sindang Indramayu lebih menekankan pada menanamkan nilai-nilai perilaku sosial dengan menekankan kesadaran dan kewaspadaan yakni dengan memotivasi dan membiasakan peserta didik berpikir analitis, kritis dan historis dan ini semuanya sudah dilakukan sejak lama, hal itu bisa dilihat dalam penyusunan atau pembuatan RPP dan Silabus pada mata pelajaran tersebut dan dari kegiatan tambahan (ekstrakurikuler) yang ada di SMK Negri 1 Sindang Indramayu.

Hasil penelitian menunjukkan bahwa kegiatan proses pembelajaran yang dilaksanakan di SMK Negri 1 Sindang Indramayu dilakukan melalui beberapa pendekatan, strategi, metode dan model. Salah satu pendekatan yang dilakukan dalam pelaksanaan pembelajaran IPS melalui pembelajaran diskusi sehingga dapat melatih sikap santun dalam berpendapat, kerja sama, saling menghormati, tidak mengganggu hak orang lain dan toleransi. Ada tiga unsur pendidikan yang meliputi tenaga pendidik, pendidik dan peserta didik dalam hal ini penerapan metode adalah suatu pengetahuan tentang cara-cara yang dipergunakan oleh seorang pendidik atau instruktur. Pengertian lain ialah teknik penyajian yang dikuasai pendidik untuk menyajikan bahan pelajaran kepada peserta didik di sekolah, baik secara individual/ klasikan, gara pelajaran itu dapat diserap, dipahami dan dimanfaatkan oleh peserta didik dengan baik.Makin baik metode mengajar, makin efektif pula pencapain tujuan (Abu; 2005: 52)

\section{Karakter Siswa di SMKN 1 Sindang Indramayu}

Hasil Observasi di lapangan menunjukan di SMKN 1 Sindang Kabupaten Indramayu mempelajari IPS dapat menumbuhkan nilai perilaku Sosial. Sebab mata pelajaran dengan mempelajari disiplin ilmu tersbut 
mampu memberikan kesadaran, kebersamaan, saling menghormati sesama makhluk sosial sehingga kita dapat merenungi, menghayati dan mendiskusikannya di dalam kelas, bahkan sampai mengikuti apa yang sekiranya baik mengingat tantangan hidup kedepan yang samakin kompleks untuk menjadi warga negara dan warga dunia yang baik serta berperilaku baik dengan memiliki dengan mengaplikasikan nilai-nilai perilaku sosial seperti santun, bekerja sama, saling menghormati, tidak mengganggu hak orang lain dan toleran dalam hidup bermasyarakat.

Toleransi merupakan suatu sikap yang saling menghargai individukelompok atau antar individu dalam masyarakat atau dalam lingkup lainnya. Toleransi juga dikatagorikan suatu perbuatan yang melarang terjadinya diskriminasi sekalipun banyak terdapat kelompok atau golongan yang berbeda dalam masyarakat. Toleran ini bisa dilihat jelas pada agama, toleransi agama sering kita jumpai di masyarakat. Adanya toleransi agama menimbulkan sikap saling menghormati masing-masing pemeluk agama.

\section{Peranan Pendidikan Karakter Siswa di SMKN 1 Sindang Indramayu}

Hasil Observasi di lapangan menunjukan pendidikan karakter SMK Negri 1 Sindang Indramayu melalui pendidik untuk sosok yang mempunyai banyak ilmu, mau mengamalkan dengan sungguh-sungguh ilmunya tersebut dalam proses pembelajaran dalam makna yang luas, toleran dan senantiasa berusaha menjadikan peserta didiknya memiliki kehidupan yang lebih baik melalui perencanaan, pelaksanaan dan keteladanan. Secara prinsip, mereka yang disebut sebagai pendidik bukan hanya mereka yang memiliki kualifikasi keguruan secara formal yang diperoleh lewat jenjang pendidikan di perguruan tinggi saja, tetapi yang terpenting adalah mereka yang mempunyai kompetensi keilmuan tertentu dan dapat menjadikan orang lain pandai dalam ranah kognitif, afektif dan psikomotorik. Ranah kognitif menjadikan peserta didik cerdas dalam aspek intelektualnya, ranah afektif menjadikan peserta didik mempunyai sikap dan perilaku yang sopan, dan ranah psikomotorik menjadikan peserta didik terampil dalam melaksanakan aktifitas secara efektif, efesien, 
serta tepat guna. Di sinilah letak pentingnya peranan seorang pendidik yang menjadi pembimbing.

Hasil penelitian menunjukkan bahwa peran pendidik dalam menanamkan nilai-nilai perilaku sosial siswa yang dilaksanakan di SMK Negri 1 Sindang Indramayu sangat relevan karena melalui kegiatan proses pendidikan IPS dapat menanamkan nilai-nilai perilaku sosial kepada siswa. Menanaman nilai-nilai perilaku sosial dilakukan dari tahap perencanaan, pelaksanaan, keteladanan dan kegiatan non akademik (ekstrakurikuler) dengan melalui kegiatan rutin, kegiatan spontan, kegiatan yang terprogram.

\section{E. KESIMPULAN DAN SARAN}

\section{Kesimpulan}

Berdasarkan hasil penelitian yang telah diuraikan oleh peneliti pada bab sebelumnya, maka dalam penelitian ini kesimpulan yang diambil adalah sebagai berikut:

a. Kegiatan pendidikan karakter yang dilaksanakan di SMKN Negeri 1 Sindang Indramayu dilakukan melalui beberapa unsur pendidikan diantaranya melalui pendekatan, strategi, metode dan model. Salah satu pendekatan yang dilakukan dalam pelaksanaan pendidikan IPS melalui pembelajaran yang efektif sehingga dapat melatih karakter siswa seperti sikap sopan santun dalam beretika, saling menghormati, dan tidak mengganggu hak orang lain.

b. Karakter siswa di SMK Negri 1 Sindang Indramayu melalui sosok pendidik atau guru yang memiliki banyak ilmu, mau mengamalkan dengan sungguh-sungguh ilmunya tersebut dalam proses pembelajaran dalam makna yang luas, toleran dan senantiasa berusaha menjadikan peserta didiknya memiliki kehidupan yang lebih baik melalui perencanaan, pelaksanaan dan keteladanan, semua itu dilakukan untuk menjadikan peserta didik cerdas bukan hanya diranah intelektualnya saja, tetapi juga dirana emosionalnya serta mempunyai perilaku yang sopan dan disiplin 
dan terampil dalam melaksanakan aktifitas secara efektif, efesien, serta tepat guna.

c. Peran pendidikan Karakter dalam menanamkan nilai-nilai, norma, etika serta dalam membentuk karaktersiswa yang dilaksanakan di SMKN Negeri 1 Sindang Indramayu sangat relevan karena melalui kegiatan proses pendampingan dalam pendidikan karakter dapat menanamkan nilai kepribadian yang baik kepada siswa. Menanamkan nilai karakter dilakukan oleh beberapa unsur pendidikan yang meliputi dari tahap perencanaan, pelaksanaan, keteladanan dan ekstrakurikuler dengan melalui kegiatan rutin, kegiatan spontan, kegiatan yang terprogram.

\section{Saran}

Dengan melihat hasil penelitian yang telah diketahui, maka peneliti memberikan tiga unsur pada pendidikan yang didalamnya memiliki saran pada pihak yang terkait dalam penelitian ini, diantaranya:

a. Kepala Sekolah SMK Negeri 1 Sindang Indramayu sebaiknya harus memberikan pengawasan dan pengembangan secara menyeluruh terhadap profisionalisme guru dalam menanamkan nilai karakter, serta dapat mencontoh dari kebaikan yang telah dilakukan oleh guru yang ada di sekolah.

b. Guru diharapkan selalu menjaga dan mengembangkan profesionalitas pendidikan dalam belajar siswa yang menanamkan nilai karakter dangan cara yang menyenangkan, sehingga peserta didik mampu menerima materi ajar dengan baik.

c. Siswa diharapkan untuk selalu berhati-hati terhadap berbagai macam dunia luar dan perubahan jaman yang begitu cepat dan diharapkan juga untuk dapat mengaplikasikan dalam kehidupan sehari-harinya yang lebih baik entah dalam lingkungan sekolah, keluarga maupun sosialnya.

\section{DAFTAR PUSTAKA}

Al-Mighwar, Muhammad. 2006. Psikologi Remaja: Petujuk Bagi Guru dan Orang Tua. Bandung: Pustaka Setia. 
Arikunto, Suharsimi. 2005. Manajemen Penelitian. Jakarta: Rineka Cipta.

Azzet, Akhmad Muhaimin. 2011. Urgensi Pendidikan Karakter di Indonesia (Revitalisasi Pendidikan Karakter terhadap Keberhasilan Belajar dan Kemajuan Bangsa, Jogjakarta, Ar-Ruzz Media.

Gunanwan, Heri. 2012. Pendidikan Karakter (Konsep dan Implementasi). Bandung : Alfabeta.

Hardianti. 2008. Kekerasan dalam Pendidikan. Jakarta: Raja Grafindo.

Kartini, Kartono. 2005.Patologi Sosial. Jakarta: RajaGrafindo.

Kertajaya H .2010. Pendidikan Karakter. Jakarta: Gramedia.

Koesoema, Doni A.2007.Pedidikan Karakter.Jakarta : Gramedia, Grasindo.

Majid, Abdul. 2010.Pendidikan Karakter dalam Perspektif Islam, Bandung : RemajaRosdakarya.

Moleong, Lexy J. 2005. Metodologi Penelitian Kualitatif. Bandung: RemajaRosdakarya.

Mu'in, Fatchul. 2011.Pendidikan Karakter Kontruksi Teoritik \& Praktik (Urgensi Pendidikan Progresif dan Peran Guru dan Orang Tua). Bandung: Remaja Rosdakarya.

Mulyono, B. 1995.Pendekatan Analisis Kenakalan Remaja dan Penanggulanganya.Yogyakarta: Kanisius.

Munir, Abdullah. 2010.Pendidikan Karakter, Yogyakarta: Pedagogia.

Soedarsono. 2004. Kenakalan Remaja. Jakarta: Rineka Cipta.

Sugiyono. 2010. Metode Penelitian Pendekatan Kuantitatif, Kualitatif dan R\&D. Bandung: Alfabeta.

Syah, Muhibbin. 2010. Psikologi Pendidikan dengan Pendkatan Baru, Bandung: Remaja Rosdakarya.

Tafsir, Ahmad. 2010. Pendidikan Karakter Perspektif Islam. Bandung: Remaja Rosdakarya. 